\title{
A comparison of oil and grease removal from automobile workshop stormwater runoff using gravel, granular activated carbon, rice husk and conventional oil and grease $(0 \& G)$ trap
}

\author{
Clement Oguche Ataguba' and Isobel Brink ${ }^{1}$ \\ 'Department of Civil Engineering, Stellenbosch University, Private Bag X1, Matieland 7602, Stellenbosch, South Africa
}

Oil and grease $(\mathrm{O} \& \mathrm{G})$ removal efficiencies using 4 automobile stormwater treatment systems were investigated and compared. The treatment systems used were: low-cost granular activated carbon-rice husk (GAC-RH) filter system, river gravel-granular activated carbon (GR-GAC) filter system, rice husk only (RH) filter system and the conventional PVC O\&G trap (COT). Sampling of automobile stormwater from the five selected automobile workshops was carried out using the manual grab sampling methods. The treatment involved filtration using the low-cost technologies and O\&G separation from stormwater. GAC-RH exhibited the highest O\&G removal with an average removal efficiency of $43.2 \%$ from all the automobile workshops, followed by RH with an average removal efficiency of 31\%. O\&G removal using GR-GAC and COT resulted in average removal efficiencies of $28.6 \%$ and $26.8 \%$, respectively. Further studies need to be carried out to optimize the GAC and RH low-cost filter materials for the purpose of achieving the USEPA and Nigerian effluent standards of $0.1 \mathrm{mg} / \mathrm{L}$, since all the treatment systems produced effluents with minimum concentrations ranging between $0.8 \mathrm{mg} / \mathrm{L}$ and $3.6 \mathrm{mg} / \mathrm{L}$.

\section{INTRODUCTION}

Stormwater runoff from different land uses has been identified as a major source of surface water pollution in any given catchment (Wang and Zhang, 2018). This results from the different materials and debris carried in the flow from point of generation to the point of discharge. Pollutants carried by runoff have potentially harmful effects on the receiving water, recreation and aquatic life (Bashir, 2020; Edokpayi et al., 2017). There are problems associated with discharging polluted stormwater into surface water without required treatment. These include increased sedimentation, changes to temperature of receiving water, decreased level of dissolved oxygen, decreased population of fish and other aquatic animals, and impairment of water quality due to nature, type and concentration of the pollutants (USEPA, 2005).

Typical stormwater runoff from automobile workshops carries metals, solids, oil and grease (O\&G), etc., as pollutants in the stream to the point of discharge. Fluid leaks from vehicles/machines; vehicle oil change spills and lubricant leaks are major sources of O\&G carried in runoff from construction sites, automobile workshops, farms, or parking lots through sheet flow or flow in storm drains (CEPA, 2006). Used oil has been reported to contain heavy metals such as cadmium, chromium, lead and nickel, which have been shown to cause acute and chronic toxicity for aquatic animals and humans (USEPA, 2000). It has been reported that O\&G contributes to more than $5 \%$ of total pollutant loads to surface water (Eganhouse and Kaplan, 1981). The discharge of stormwater containing O\&G without treatment causes lethal effects on aquatic life as well as adverse aesthetics effects on the environment (Pintor et al., 2016; USEPA, 1986). This is mostly due to the fact that O\&G from vehicles/machines are nonbiodegradable compounds (USACE, 2016).

Two major strategies that have been considered in the management of O\&G in stormwater and wastewater are source-control restriction of $O \& G$ discharge into the watershed and end-of-pipe treatment before discharge into the receiving water (CEPA, 2006). Different methods of removal from storm/wastewater, which include electrical, chemical, electro-chemical, bio-chemical and physical techniques, have been reported in literature (Young, 1979; Kulowiec, 1979; Roggatz and Klute, 1988; Karakulski et al., 1995). These methods have been found to have financial, technical and efficiency implications. These implications have been reported to translate to high energy consumption, skilled labour requirement, high operation and maintenance cost, poor management of waste/sludge generated, as well as a large footprint required for treatment (Capodaglio and Olsson, 2020; Stefanakis, 2020). The most common conventional method, of using a skimming tank with O\&G trap, has been reported to have low efficiency (El-Gawad, 2014).

The potential of agricultural waste materials (sugarcane bagasse and banana pith) was explored by Hamid et al. (2016) for the adsorption of O\&G from wastewater, and it was discovered that sugarcane bagasse was capable of removing up to $63 \%$ of O\&G with $5 \mathrm{~g}$ adsorbent weight, and up to $56 \%$ removal with 75 min contact time was also achieved. Similarly, banana pith achieved up to $97 \%$ O\&G removal with $5 \mathrm{~g}$ adsorbent weight and $60 \mathrm{~min}$ contact time.

The application of innovative solutions for the removal of O\&G from automobile workshop stormwater runoff is required to enhance environmental health. In this research, O\&G removal efficiencies

\section{CORRESPONDENCE}

Clement Oguche Ataguba

\section{EMAIL}

clematrix2008@gmail.com

\section{DATES}

Received: 15 June 2021

Accepted: 21 December 2021

\section{KEYWORDS}

automobile workshop effluent concentration low-cost treatment technology oil and grease removal efficiency stormwater treatment

\section{COPYRIGHT}

() The Author(s) Published under a Creative Commons Attribution 4.0 International Licence (CC BY 4.0) 
Table 1. Details of design equations, data and references for the filter designs (See Ataguba and Brink, 2021a)

\begin{tabular}{|c|c|c|c|c|}
\hline Filter & Design equation & Design data & & Reference \\
\hline GR filter design & $\begin{array}{l}V_{\mathrm{f}}\left(\frac{m}{h}\right)=\frac{Q}{A}=Q \div \frac{\pi D^{2}}{4} \\
\operatorname{Density} \rho=\frac{\operatorname{mass}(m)}{\operatorname{volume}(v)}\end{array}$ & $\begin{array}{l}\text { Depth of column } \\
\text { Height of filter } \\
\text { Freeboard } \\
\text { Diameter of column } \\
\text { Volume of gravel } \\
\text { Density of gravel } \\
\text { Mass of gravel } \\
\text { Filtration rate } \\
\text { Flow rate }\end{array}$ & $\begin{array}{l}H=0.40 \mathrm{~m} \\
L=0.3 \mathrm{~m} \\
t=0.10 \mathrm{~m} \\
D=0.10 \mathrm{~m} \\
V_{\mathrm{G}}=0.0024 \mathrm{~m}^{3} \\
\rho_{\mathrm{G}}=1400 \mathrm{~kg} / \mathrm{m}^{3} \\
M_{\mathrm{G}}=3.4 \mathrm{~kg} \\
V_{\mathrm{f}}=1.0 \mathrm{~m} / \mathrm{h} \\
Q=0.008 \mathrm{~m}^{3} / \mathrm{h}\end{array}$ & $\begin{array}{l}\text { Wegelin (1996): } \\
\text { density-mass-volume } \\
\text { relation }\end{array}$ \\
\hline GAC filter design & $\begin{array}{l}\mathrm{EBCT}=\frac{V}{Q}=\frac{A \times L}{Q} \\
\text { Density } \rho=\frac{\operatorname{mass}(m)}{\operatorname{volume}(v)}\end{array}$ & $\begin{array}{l}\text { Depth of column } \\
\text { Height of filter } \\
\text { Freeboard } \\
\text { Diameter of column } \\
\text { Volume of GAC } \\
\text { Density of GAC } \\
\text { Mass of GAC } \\
\text { Empty bed contact time }\end{array}$ & $\begin{array}{l}H=0.40 \mathrm{~m} \\
L=0.30 \mathrm{~m} \\
t=0.10 \mathrm{~m} \\
D=0.10 \mathrm{~m} \\
V_{\mathrm{GAC}}=0.0024 \mathrm{~m}^{3} \\
\rho_{\mathrm{GAC}}=650 \mathrm{~kg} / \mathrm{m}^{3} \\
M_{\mathrm{GAC}}=1.56 \mathrm{~kg} \\
\mathrm{EBCT}=18 \mathrm{mins}\end{array}$ & $\begin{array}{l}\text { USACE (2001): } \\
\text { density-mass-volume } \\
\text { relation }\end{array}$ \\
\hline RH filter design & Density $\rho=\frac{\operatorname{mass}(m)}{\text { volume }(v)}$ & $\begin{array}{l}\text { Depth of column } \\
\text { Height of filter } \\
\text { Freeboard } \\
\text { Diameter of column } \\
\text { Volume of } \mathrm{RH} \\
\text { Density of } \mathrm{RH} \\
\text { Mass of RH }\end{array}$ & $\begin{array}{l}H=0.40 \mathrm{~m} \\
L=0.30 \mathrm{~m} \\
t=0.10 \mathrm{~m} \\
D=0.10 \mathrm{~m} \\
V_{\mathrm{RH}}=0.0024 \mathrm{~m}^{3} \\
\rho_{\mathrm{RH}}=100 \mathrm{~kg} / \mathrm{m}^{3} \\
M_{\mathrm{RH}}=0.24 \mathrm{~kg}\end{array}$ & $\begin{array}{l}\text { Density-mass-volume } \\
\text { relation }\end{array}$ \\
\hline
\end{tabular}

of 4 automobile stormwater treatment systems were investigated and compared. The treatment systems developed for this study were: granular activated carbon-rice husk (GAC-RH) filter system, river gravel-granular activated carbon (GR-GAC) filter system, rice husk only (RH) filter system and the conventional PVC O\&G trap (COT).

\section{METHODOLOGY}

Gravel, activated carbon and rice husk are readily available filter materials in Nigeria, at low or no cost. The gravel (concrete construction material) was obtained at minimal cost from a mining site on the bank of the River Niger, while the rice husk (waste from rice milling) was obtained from the rice mill in Idah, Nigeria. Raw carbon (material from wood combustion) was procured from local carbon dealers. The thermal activation (pyrolysis) of the raw carbon produced activated carbon as described in McDougall (1991) The $100 \mathrm{~mm}$ PVC pipes that were used to construct the filter columns were also sourced from the same town. A medium-size commercially available conventional O\&G trap (COT) was procured and used. The COT used was a simple transparent funnel-like water and $O \& G$ separator with a stop cork that controlled the effluent discharge as well as regulated the separation of the O\&G from the effluent. The columns and the different filters (treatment technologies) were designed based on design data shown in Table 1 and adapted from Ataguba and Brink (2021a). The low-cost material filters were further configured as GAC-RH (combined GAC and RH filter; GR-GAC (combined GR and GAC filter) and RH-only filter.

Details of 5 selected automobile workshops from the study locations in Nigeria have been reported in Ataguba and Brink (2021b). Table 2 shows the details of the selected automobile workshops as adapted from Ataguba and Brink (2021b), while Fig. 1 shows the satellite imagery map of the study locations.

Sampling of automobile stormwater runoff was carried out using the manual grab sampling methods described in Lowe et al. (2018), where 3 samples (1.5 L each) per automobile workshop per week, for a period of 9 weeks, were obtained from catch-pits downstream of the workshops.
Table 2. Details of selected automobile workshops for the study (Source: Ataguba and Brink, 2021b)

\begin{tabular}{lccc}
\hline Label & Location & $\begin{array}{c}\text { Approximate } \\
\text { area }\left(\mathrm{m}^{2}\right)\end{array}$ \\
\hline Workshop 1 & Idah & $7^{\circ} 05^{\prime} 0^{\prime \prime} \mathrm{N}, 6^{\circ} 45^{\prime} 0^{\prime \prime} \mathrm{E}$ & 1600 \\
Workshop 2 & Idah & & 1800 \\
Workshop 3 & Idah & & 1600 \\
\hline Workshop 4 & Lokoja & $7^{\circ} 48^{\prime} 32^{\prime \prime} \mathrm{N}, 6^{\circ} 44^{\prime} 15^{\prime \prime} \mathrm{E}$ & 3600 \\
Workshop 5 & Lokoja & & 2400 \\
\hline
\end{tabular}

The filtration procedure described in Ataguba and Brink (2021a) was used. Briefly, the raw stormwater from the different automobile workshops (influents) were fed into the different filter setups as shown in Fig. 2. The filtrates flow by gravity through all the filters designed and constructed, at a flow rate of $0.008 \mathrm{~m}^{3} / \mathrm{h}$ (Table 1). Raw stormwater was also fed into the COT. The stop cork was manually operated and the effluents flow from the COT into the effluent collectors until a point was reached when the $\mathrm{O} \& \mathrm{G}$ at the top of the influent in the COT is observed to be at the base of the apparatus when the stop cork was locked. The influents as well as the final effluents from the different filter systems and the $O \& G$ traps were analysed for O\&G over the entire testing duration of 9 weeks. The laboratory analyses were carried out in accordance with APHA (2017) and Method 1664B (USEPA, 2010). The average O\&G concentration results of the influents and effluents from the different treatment systems obtained are presented in Fig. 3. Similarly, the average O\&G removal efficiency was computed for each treatment system using Eq. 1 as adapted from Ataguba and Brink (2021a), and presented in Fig. 4.

$$
T_{\mathrm{e}}(\%)=\frac{C_{\mathrm{i}}-C_{\mathrm{e}}}{C_{\mathrm{i}}} \times 100
$$

where: $T_{\mathrm{e}}=\mathrm{O} \& \mathrm{G}$ removal efficiency of the treatment system, $C_{\mathrm{i}}=$ concentration of influent $\mathrm{O} \& \mathrm{G}, C_{\mathrm{e}}=$ concentration of effluent O\&G for GAC-RH, GR-GAC or RH treatment system. 


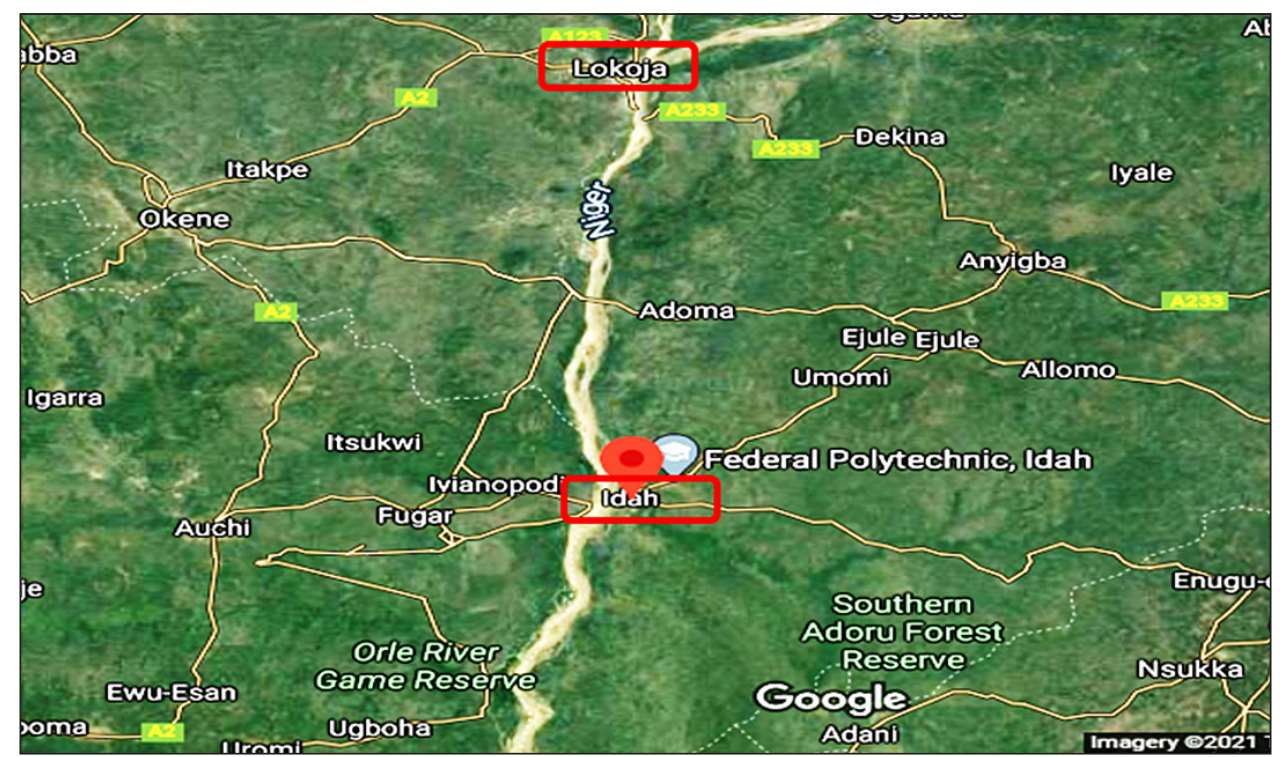

Figure 1. Satellite imagery map of the study locations (Source: Google Maps as cited in Ataguba and Brink, 2021b)

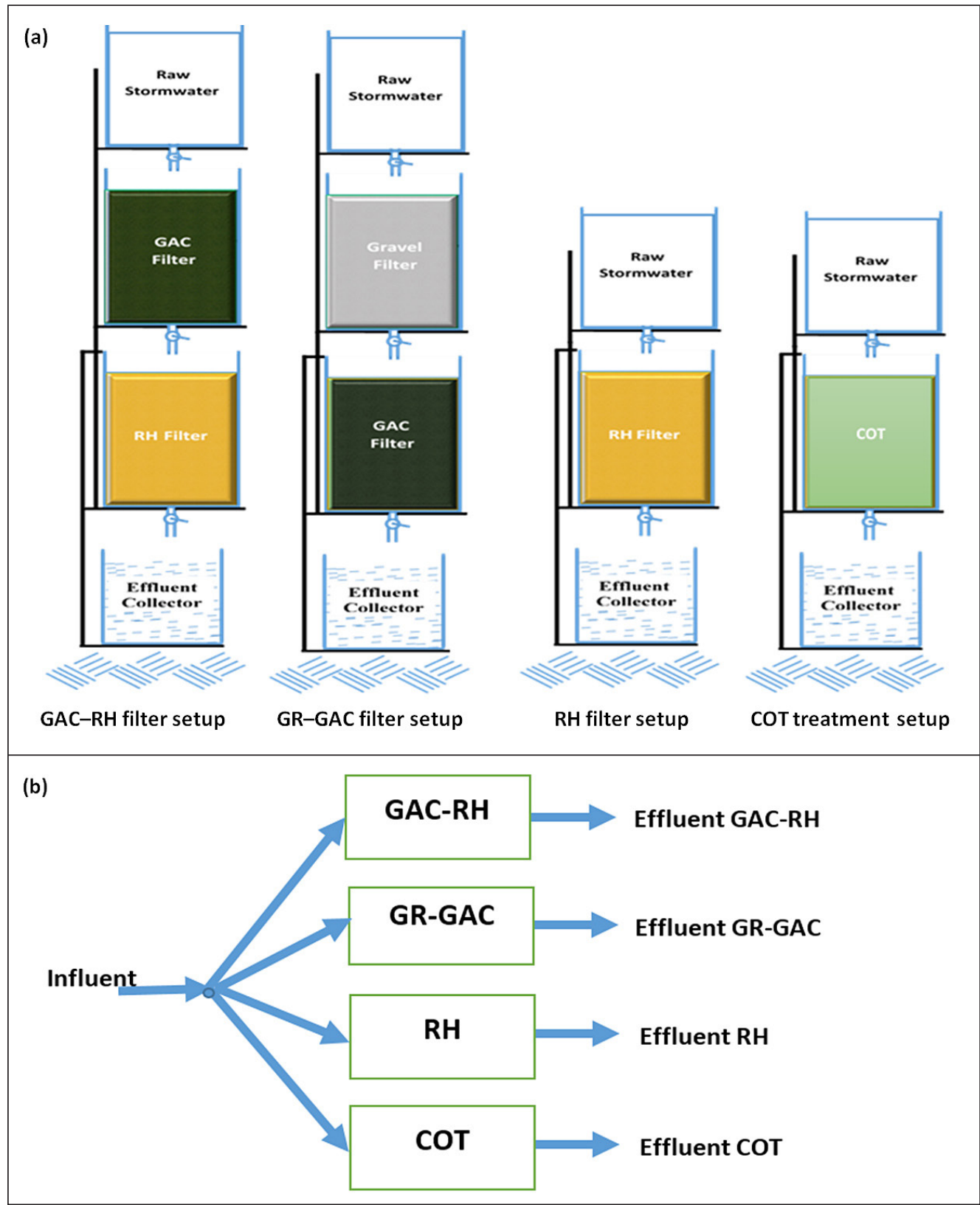

Figure 2. Schematic of the (a) treatment set-ups (modified from Ataguba and Brink, 2021a) and (b) influent-effluent relationship 


\section{RESULTS AND DISCUSSION}

The box plots in Figs 3 and 4 show the results of the influent and effluent analyses. Figure 3 shows that the original concentration of O\&G in Automobile Workshop 1 stormwater was reduced on average from $5.2 \mathrm{mg} / \mathrm{L}$ to $3.0 \mathrm{mg} / \mathrm{L}$ using GAC-RH; $3.8 \mathrm{mg} / \mathrm{L}$ using GR-GAC; $3.8 \mathrm{mg} / \mathrm{L}$ using $\mathrm{RH}$ and $3.9 \mathrm{mg} / \mathrm{L}$ using COT treatments, respectively. These reductions corresponded to $43 \%$, $29 \%, 28 \%$ and $26 \%$ O\&G removal for the mentioned treatment systems, respectively, as shown in Fig. 4.

In Automobile Workshop 2, the concentration of O\&G in the stormwater runoff samples reduced from $5.0 \mathrm{mg} / \mathrm{L}$ to $2.8 \mathrm{mg} / \mathrm{L}$ using GAC-RH; $3.6 \mathrm{mg} / \mathrm{L}$ using GR-GAC; $3.5 \mathrm{mg} / \mathrm{L}$ using $\mathrm{RH}$ and $3.7 \mathrm{mg} / \mathrm{L}$ using COT treatments, respectively, as shown in Fig. 3. Similarly, from Fig. 4, these reductions in O\&G concentrations corresponded to $45 \%, 28 \%, 31 \%$ and $26 \%$ O\&G removal efficiencies by the respective treatment systems.

In Automobile Workshop 3, the concentration of O\&G in the stormwater runoff samples reduced from $5.1 \mathrm{mg} / \mathrm{L}$ to $3.2 \mathrm{mg} / \mathrm{L}$ using GAC-RH; $3.8 \mathrm{mg} / \mathrm{L}$ using GR-GAC; $3.9 \mathrm{mg} / \mathrm{L}$ using $\mathrm{RH}$ and $4.0 \mathrm{mg} / \mathrm{L}$ using COT treatments, respectively. These corresponded to $38 \%, 28 \%, 22 \%$ and $20 \%$ O\&G removal efficiencies by the respective treatment systems.
In Automobile Workshop 4, the average concentration of O\&G in the stormwater runoff samples reduced from $6.1 \mathrm{mg} / \mathrm{L}$ to $3.0 \mathrm{mg} / \mathrm{L}$ using GAC-RH; $4.4 \mathrm{mg} / \mathrm{L}$ using GR-GAC; $3.7 \mathrm{mg} / \mathrm{L}$ using $\mathrm{RH}$ and $4.0 \mathrm{mg} / \mathrm{L}$ using COT treatments, respectively. These corresponded to $49 \%, 28 \%, 40 \%$ and $33 \%$ O\&G removal efficiencies by the respective treatment systems.

In Automobile Workshop 5, the average concentration of O\&G in the stormwater runoff samples reduced from $6.2 \mathrm{mg} / \mathrm{L}$ to $3.4 \mathrm{mg} / \mathrm{L}$ using GAC-RH, to $4.4 \mathrm{mg} / \mathrm{L}$ using GR-GAC, and to $4.1 \mathrm{mg} / \mathrm{L}$ using RH and $4.3 \mathrm{mg} / \mathrm{L}$ using COT treatments, respectively. These reductions corresponded to $44 \%, 29 \%, 34 \%$ and $29 \%$ O\&G removal efficiencies by the respective treatment systems.

The box plot (Fig. 3) shows that the minimum concentrations of GAC-RH treatment of $\mathrm{O} \& \mathrm{G}$ for all the automobile workshops ranged from $0.8 \mathrm{mg} / \mathrm{L}$ at Automobile Workshop 2 to $2.58 \mathrm{mg} / \mathrm{L}$ at Automobile Workshop 5. For the GR-GAC treatment of O\&G, the minimum concentrations of O\&G ranged from $2.65 \mathrm{mg} / \mathrm{L}$ at Automobile Workshop 1 to $3.6 \mathrm{mg} / \mathrm{L}$ at Automobile Workshop 4. Similarly, for the $\mathrm{RH}$ treatment of $\mathrm{O} \& \mathrm{G}$, the minimum concentrations of $\mathrm{O} \& \mathrm{G}$ ranged from $1.04 \mathrm{mg} / \mathrm{L}$ at Automobile Workshop 1 to $3.1 \mathrm{mg} / \mathrm{L}$ at Automobile Workshop 5. The minimum concentrations of COT treatment of $\mathrm{O} \& \mathrm{G}$ for all the automobile workshops ranged from $1.8 \mathrm{mg} / \mathrm{L}$ at Automobile Workshop 1 to $3.6 \mathrm{mg} / \mathrm{L}$ at Automobile Workshop 5 .

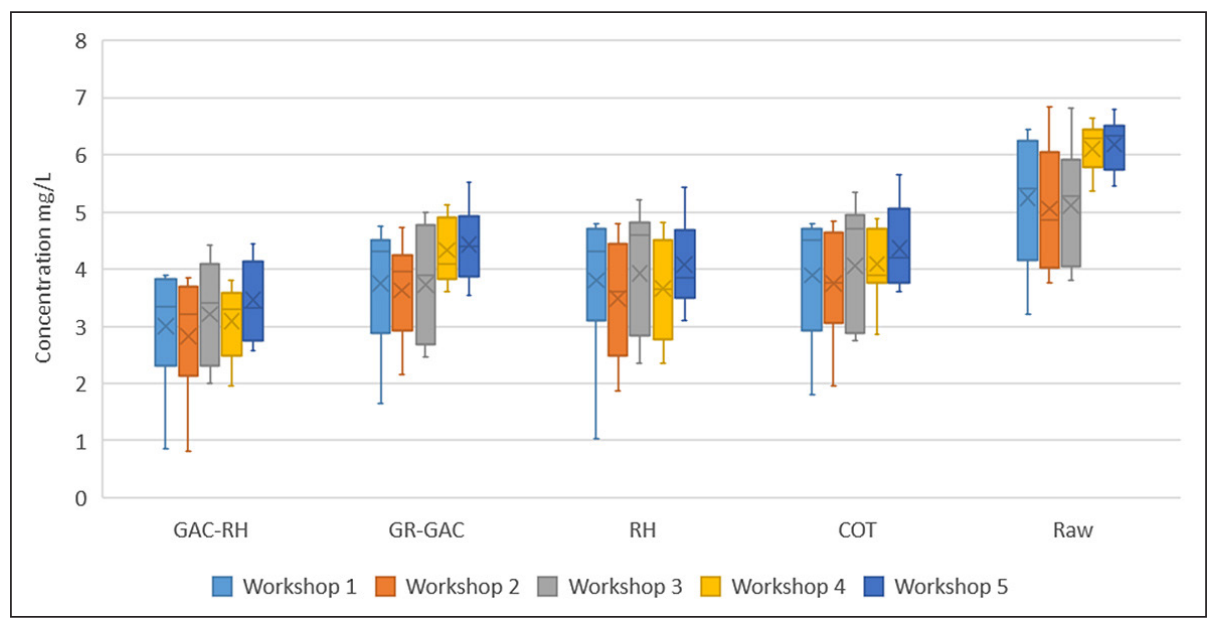

Figure 3. Concentrations of O\&G in the influent (raw sample) and the effluents from the different treatment systems

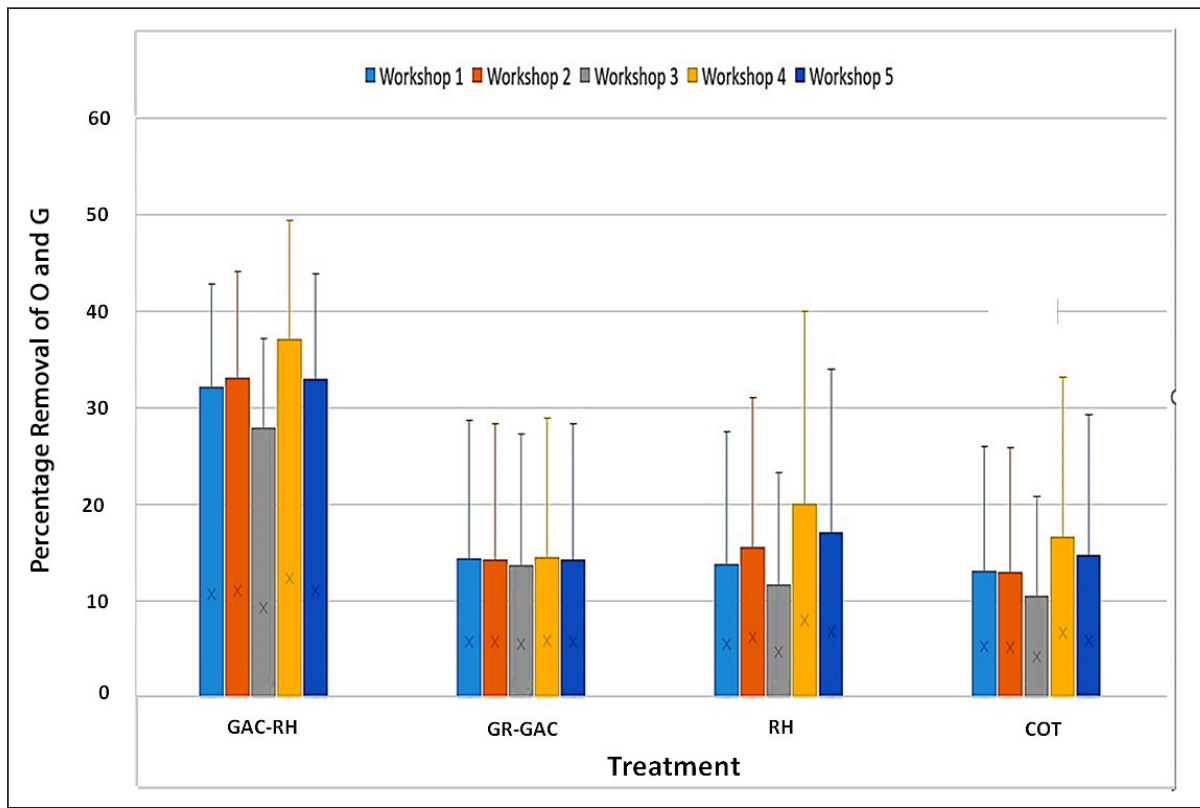

Figure 4. Percentage $O \& G$ removal efficiencies from the different treatment systems 
Table 3. Concentration and percentage removal ranges of $O \& G$ treatment technologies

\begin{tabular}{|c|c|c|c|c|}
\hline $\begin{array}{l}\text { Treatment } \\
\text { technology }\end{array}$ & $\begin{array}{l}\text { Maximum concentration } \\
\text { range }(\mathrm{mg} / \mathrm{L})\end{array}$ & $\begin{array}{l}\text { Minimum concentration } \\
\text { range }(\mathrm{mg} / \mathrm{L})\end{array}$ & $\begin{array}{c}\text { Median concentration } \\
\text { range }(\mathrm{mg} / \mathrm{L})\end{array}$ & $\begin{array}{l}\text { O\&G percentage } \\
\text { removal range (\%) }\end{array}$ \\
\hline \multirow[t]{2}{*}{ GAC-RH } & $3.8-4.45$ & $0.8-2.58$ & $2.83-3.46$ & \\
\hline & Automobile Workshops 4 and 5 & Automobile Workshops 2 and 5 & Automobile Workshops 2 and 5 & $37-49$ \\
\hline \multirow[t]{2}{*}{ GR-GAC } & $4.72-5.52$ & $2.65-3.6$ & $3.62-4.43$ & \\
\hline & Automobile Workshops 2 and 5 & Automobile Workshops 1 and 4 & Automobile Workshops 2 and 5 & $26-29$ \\
\hline \multirow[t]{2}{*}{$\mathrm{RH}$} & $4.8-5.44$ & $1.04-3.1$ & $3.49-4.08$ & \\
\hline & Automobile Workshops 1 and 5 & Automobile Workshops 1 and 5 & Automobile Workshops 2 and 5 & $23-40$ \\
\hline \multirow[t]{2}{*}{ COT } & $4.8-5.65$ & $1.8-3.6$ & $3.75-4.37$ & \\
\hline & Automobile Workshops 1 and 5 & Automobile Workshops 1 and 5 & Automobile Workshops 2 and 5 & $22-34$ \\
\hline
\end{tabular}

Table 4. Order of performance of treatment methods

\begin{tabular}{lc}
\hline Filtration material & Average O\&G removal efficiency (\%) \\
\hline Granular activated carbon-rice husk (GAC-RH) & 43.2 \\
Rice husk only (RH) & 31.0 \\
Gravel-granular activated carbon (GR-GAC) & 28.6 \\
Conventional O\&G trap (COT) & 26.8 \\
\hline
\end{tabular}

The box plot also shows that the maximum concentrations of GAC-RH treatment of O\&G for all the automobile workshops ranged from $3.8 \mathrm{mg} / \mathrm{L}$ at Automobile Workshop 4 to $4.45 \mathrm{mg} / \mathrm{L}$ at Automobile Workshop 5. For the GR-GAC treatment of O\&G, the maximum concentrations of O\&G ranged from $4.72 \mathrm{mg} / \mathrm{L}$ at Automobile Workshop 2 to $5.52 \mathrm{mg} / \mathrm{L}$ at Automobile Workshop 5. Similarly, for the RH treatment of $O \& G$, the maximum concentrations of O\&G ranged from $4.8 \mathrm{mg} / \mathrm{L}$ at Automobile Workshop 1 to $5.44 \mathrm{mg} / \mathrm{L}$ at Automobile Workshop 5. The maximum concentrations of COT treatment of O\&G for all the automobile workshops ranged from $4.8 \mathrm{mg} / \mathrm{L}$ at Automobile Workshop 1 to $5.65 \mathrm{mg} / \mathrm{L}$ at Automobile Workshop 5.

The median concentrations of GAC-RH treatment of O\&G for all the automobile workshops ranged from $2.83 \mathrm{mg} / \mathrm{L}$ at Automobile Workshop 2 to $3.46 \mathrm{mg} / \mathrm{L}$ at Automobile Workshop 5. For the GR-GAC treatment of O\&G, the median concentrations of O\&G ranged from $3.62 \mathrm{mg} / \mathrm{L}$ at Automobile Workshop 2 to $4.43 \mathrm{mg} / \mathrm{L}$ at Automobile Workshop 5. Similarly, for the RH treatment of $\mathrm{O} \& \mathrm{G}$, the median concentrations of O\&G ranged from $3.49 \mathrm{mg} / \mathrm{L}$ at Automobile Workshop 2 to $4.08 \mathrm{mg} / \mathrm{L}$ at Automobile Workshop 5. The median concentrations of COT treatment of O\&G for all the automobile workshops ranged from $3.75 \mathrm{mg} / \mathrm{L}$ at Automobile Workshop 2 to $4.37 \mathrm{mg} / \mathrm{L}$ at Automobile Workshop 5. The maximum, minimum and median concentration ranges explained above have been summarized in Table 3 .

It was observed from the results that the different treatment systems exhibited different levels of removal efficiency for O\&G. Interestingly, it was found that the low-cost filter materials competed favourably with the conventional $O \& G$ trap. This research has shown that the removal achieved by adsorption of O\&G onto the adsorbents (GAC and $\mathrm{RH}$ ) was higher than that by ordinary filtration by the conventional O\&G trap (COT).

Comparing these treatment methods from the results shown in Figs 2 and 3, GAC-RH exhibited the highest O\&G removal with an average removal efficiency of $43.2 \%$ for all the automobile workshops, followed by RH with an average removal efficiency of $31 \%$. The order of performance of each treatment technology is shown in Table 4.

Additionally, it was observed that the concentrations obtained from these treatment systems were higher than the USEPA
(1986) and NESREA (2011) maximum limits of $0.1 \mathrm{mg} / \mathrm{L}$. This indicates that optimization of filters, possibly in combination with a treatment train approach of multiple filters, may be required to bring O\&G stormwater concentrations down to acceptable levels for environmental discharge.

Results obtained from a related research work on the assessment of the sustainability of the use of GAC-RH and GR-GAC in the removal of metals (Ataguba and Brink, 2021c) have shown that low inputs of operation and maintenance are required in the use of these low-cost technologies, due to low labour cost and local availability of filter materials. The study also revealed that the GAC-RH combined filters showed a slightly higher overall sustainability when compared with GR-GAC combined filters. Further research into production of larger units of GAC-RH filter technology perhaps for slow oil and grease removal, is warranted.

\section{CONCLUSION}

The concentration of $\mathrm{O} \& \mathrm{G}$ in stormwater runoff from automobile workshops has been reported to be harmful to the ecology and aquatic animals when discharged into receiving water without treatment. This study has reported the comparison of 4 treatment technologies for O\&G removal from automobile workshop stormwater runoff. The study has shown that all the technologies remove $\mathrm{O} \& \mathrm{G}$ from the automobile stormwater but the remaining concentration is still over the limit for discharge given by USEPA and Nigerian standards. It is recommended that further studies be carried out to optimize the GAC and RH low-cost filter materials for this purpose.

\section{REFERENCES}

APHA (2017) Standard Methods for the Examination of Water and Wastewater $\left(23^{\text {rd }}\right.$ edn). American Public Health Association, Washington DC.

ATAGUBA CO and BRINK IC (2021a) Design and construction of laboratory scale activated carbon, gravel and rice husk filter columns for the treatment of stormwater runoff from automobile workshops: a technical note. J. S. Afr. Inst. Civ. Eng. 63 (1) 61-66. https://doi. org/10.17159/2309-8775/2021/v63n1a6

ATAGUBA CO and BRINK IC (2021b) Characterization and assessment of stormwater runoff quality from automobile workshops in Nigeria using multivariate linear regression. Nat. Environ. Pollut. Technol. 20 (5) Suppl., 2021. https://doi.org/10.46488/NEPT.2021.v20i05.006 
ATAGUBA CO and BRINK IC (2021c) Sustainability assessment indicator selection and scoring of GAC-RH and GR-GAC combined filters for the removal of metals from automobile workshop stormwater runoff in Nigeria. International Conference on Sustainable Technology and Development, 31 October - 2 November 2021, Shenzhen.

BASHIR I, LONE FA, BHAT RA, MIR SA, DAR ZA and DAR ZA (2020) Concerns and threats of contamination on aquatic ecosystems. In: Hakeem K, Bhat $\mathrm{R}$ and Qadri $\mathrm{H}$ (eds) Bioremediation and Biotechnology. Springer, Cham. https://doi.org/10.1007/978-3-03035691-0_1

CAPODAGLIO AG and OLSSON G (2020) Energy Issues in sustainable urban wastewater management: use, demand reduction and recovery in the urban water cycle. Sustainability. 12 (266). https:// doi.org/10.3390/su12010266

CEPA (California Environmental Protection Agency) (2006) Characterization of used oil in stormwater runoff in California Office of Environmental Health Hazard Assessment, California Environmental Protection Agency.

EDOKPAYI JN, ODIYO JO and DUROWOJU OS (2017) Impact of wastewater on surface water quality in developing countries: a case study of South Africa. In: Tutu H (ed.) Water Quality. InTech. https://doi.org/10.5772/66561

EGANHOUSE RP and KAPLAN IR (1981) Extractable organic matter in urban stormwater runoff. 1. Transport dynamics and mass emission rates. Environ. Sci. Technol. 15 (3) 310-315. https://doi.org/10.1021/ es00085a007

EL-GAWAD HSA (2014) O\&G removal from industrial wastewater using new utility approach. Adv. Environ. Chem. 2014 Article ID 916878. https://doi.org/10.1155/2014/916878

HAMID NSA, MALEK NAC, MOKHTAR H, MAZLAN WS, and TAJUDDIN RM (2016) Removal of O\&G from wastewater using natural adsorbents. J. Teknol. (Sciences \& Engineering). 78 5-3 (97102). https://doi.org/10.11113/jt.v78.8519

KARAKULSKI K, KOZLOWSKI A and MORAWSKI A (1995) Purification of oily wastewater by ultrafiltration. Sep. Technol. 5 (4) 197-205. https://doi.org/10.1016/0956-9618(95)00123-9

KULOWIEC JJ (1979) Techniques for removing O\&G from industrial wastewater. Pollut. Eng. 11 (2) 49-52.

LOWE J, DELEON D, COLLINS J, HOOVER R and BOOK S (2018) Standard operating procedure for collecting grab samples from stormwater discharges. v1.1. Washington State Department of Ecology, Olympia, WA. Publication No. 18-10-023. 15 pp. https:// fortress.wa.gov/ecy/publications/summarypages/1810023.html.
NESREA (2011) National Environmental (Surface and Ground Water Quality Control) Regulations. National Environmental Standards and Regulations Enforcement Agency. Federal Ministry of Environment. Federal Republic of Nigeria Official Gazette. 98 (49).

PINTOR AMA, VILAR VJP, BOTELHO CMS and BOAVENTURA RAR (2016) O\&G removal from wastewaters: Sorption treatment as an alternative to state-of-the-art technologies. A critical review. Chem. Eng. J. 297 229-255. https://doi.org/10.1016/j.cej.2016.03.121

ROGGATZ H and KLUTE R (1988) Chemically supported O\&G removal in municipal wastewater treatment plants. In: $\mathrm{Hahn} \mathrm{HH}$ and Klute R (eds) Pretreatment in Chemical Water and Wastewater Treatment. Springer, Berlin. https://doi.org/10.1007/978-3-642-738 19-7_22.

STEFANAKIS AI (2020) Constructed wetlands for sustainable wastewater treatment in hot and arid climates: opportunities, challenges and case studies in the Middle East. Water. 12 (1665). https://doi.org/10.3390/w12061665

USACE (United States Army Corps of Engineers) (2016) Engineering Design: Lubricants and Hydraulic Fluids. Engineer Manual 1110-21424. United States Army Corps of Engineers.

USEPA (United States Environmental Protection Agency) (2010) Method 1664 Revision B: n-Hexane extractable material (HEM; O\&G) and silica gel treated n-hexane extractable material (SGTHEM; non-polar material) by extraction and gravimetry. USEPA, Washington DC. 35 pp.

USEPA (United States Environmental Protection Agency) (2005) National management measures to control nonpoint source pollution from urban areas. EPA-841-B-05-004. November, 2005. United States Environmental Protection Agency.

USEPA (United States Environmental Protection Agency) (2000) Water Quality Standards; Establishment of numeric criteria for priority toxic pollutants for the State of California; Rule. Federal Register. 65 (97) 31682-31719. May 18, 2000. USEPA, Washington DC.

USEPA (1986) Quality Criteria for Water. United States Environmental Protection Agency Office of Water Regulations and Standards, Washington DC 20460. Report No. 440/5-86-001.

WANG X and ZHANG F (2018) Effects of land use/cover on surface water pollution based on remote sensing and 3D-EEM fluorescence data in the Jinghe Oasis. Sci. Rep. 8 13099. https://doi.org/10.1038/ s41598-018-31265-0.

YOUNG JC (1979) Removal of grease and oil by biological treatment process. Water Pollut. Control Fed. 51 (8) 2071-2087. 